\title{
The strength analysis of new W-shape resilient wheel under different working conditions
}

\author{
Tian Jianhui ${ }^{1,}$ a , Wang $\mathrm{Ke}^{1}$ \\ ${ }^{1}$ CAE Analysis Room for Engineering Applications, School of Mechatronic Engineering, Xi'an \\ Technological University, Xi'an 710032, China \\ aemail: tianjianhui8@hotmail.com
}

Keywords: W-shape elastic wheels. Strength analysis. Rubber body.

Abstract. This paper presents a new W-shape resilient wheel and bases on "UIC510-5 Technical approval of monolithic wheels (2003)" standard for strength analysis. The calculation results show that in five kinds of working conditions, the elastic components strength of wheel meets the design requirements. New W-shape resilient wheel is proposed, has good application and reference value to the study of resilient wheel.

\section{Introduction}

Convenience of subway is more and more get the favour of people, and vigorously develop in the major cities. But at the same time, People pay more attention to the negative impact of noise to the environment caused by the subway operation noise pollution $[1,2]$. The design of metro vehicle speed in our country is in commonly $80 \mathrm{~km} / \mathrm{h}$. The noise produced by the subway operation is mainly for the rolling noise [3, 4]. As a result, the control of wheel noise, has the vital significance to reduce the noise of the subway operation. Using elastic wheel can significantly reduce the wheel/rail noise and the action of wheel/rail force [5]. From the viewpoint of vehicle dynamics, adding the rubber body between the wheel rim with the wheel center, which can reduce the unsprung mass and reduce the vertical acceleration between wheel/rail, can improve the brim abrasion also.

\section{The structure of $\mathbf{W}$-shape resilient wheel}

Base on a certain type of standard wheel, designing a w-shaped resilient wheel model. The resilient wheel model structure is shown in figure 1. A total of 12 pieces of rubber, using the block type is evenly distributed between wheel center with wheel rim. The vehicle load in turn through the axle passed to wheel hub, wheel center and rubber body, wheel rim and rail. Wheel rim, fixed ring, and wheel heart all interference contact with the rubber body. Wheel center and fixed ring connect by bolt. The movement of the wheel rim along the radial is slightly space.
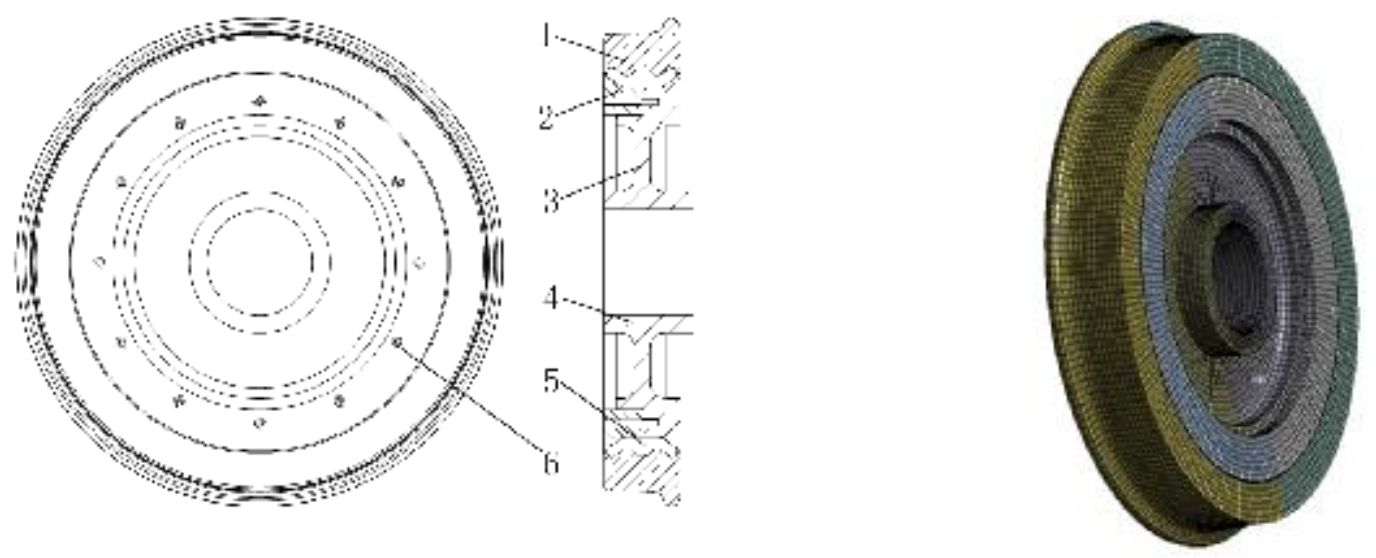

1 wheel rim; 2 fixed ring; 3 wheel center; 4 wheel

hub; 5 rubber body; 6 bolt

Fig. $1 \mathrm{~W}$-shape resilient wheel diagram

Fig. 2 Finite element model of resilient wheel 


\section{The finite element analysis of elastic wheel}

The discrete model of resilient wheel. Simplify elastic wheel model, ignoring the small size geometry characteristic, such as surface chamfer and bolt hole geometry characteristic, which will not affect the calculation. Rubber body adopts tetrahedral mesh, the rest parts use hexahedral grid. The calculation model in total has 165353 elements and 88044 nodes. Finite element model of elastic wheel is shown in figure 2.

The material parameters of resilient wheel. Wheel Rim, fixed ring and wheel center adopt CL60, rubber body use natural rubber and the shore hardness is 70 degrees. The physical properties of the material parameter are shown in table 1.

Tab. 1 The physical properties of the material parameter

\begin{tabular}{|l|l|l|l|l|l|l|l|l|}
\hline & $\begin{array}{l}\text { Density } \\
\left(\mathrm{g} / \mathrm{cm}^{3}\right)\end{array}$ & $\begin{array}{l}\text { Elasticity } \\
\text { modulus } \\
(\mathrm{MPa})\end{array}$ & $\begin{array}{l}\text { Poisson's } \\
\text { ratio }\end{array}$ & $\begin{array}{l}\text { Ultimate } \\
\text { strength } \\
(\mathrm{MPa})\end{array}$ & $\begin{array}{l}\text { Yield } \\
\text { strength } \\
(\mathrm{MPa})\end{array}$ & $\begin{array}{l}\text { Allowabl } \\
\text { estress } \\
(\mathrm{MPa})\end{array}$ & $\begin{array}{l}\mathrm{C} 10 \\
(\mathrm{MPa})\end{array}$ & $\begin{array}{l}\mathrm{C} 01 \\
(\mathrm{MPa})\end{array}$ \\
\hline $\begin{array}{l}\text { CL60 } \\
\text { Natural } \\
\text { rubber }\end{array}$ & 7.8 & 210000 & 0.3 & 1000 & 600 & 500 & & \\
\hline
\end{tabular}

Tab. 2 Load value of each working condition

\begin{tabular}{|l|l|l|l|l|}
\hline $\begin{array}{l}\text { operating } \\
\text { conditions }\end{array}$ & $\begin{array}{l}\text { radial } \\
(\mathrm{N})\end{array}$ & $\begin{array}{l}\text { Load } \\
(\mathrm{N})\end{array}$ & $\begin{array}{l}\text { axial } \\
(\mathrm{N})\end{array}$ & $\begin{array}{l}\text { Load } \\
(\mathrm{N})\end{array}$ \\
\hline $\begin{array}{l}\text { linear } \\
\text { condition }\end{array}$ & $F_{z 1}$ & 73575 & & \\
\hline $\begin{array}{l}\text { curve } \\
\text { condition }\end{array}$ & $F_{z 2}$ & 73575 & $F_{y 2}$ & 41202 \\
\hline turnout & $F_{z 3}$ & 73575 & $F_{y 3}$ & 24721 \\
\hline $\begin{array}{l}\text { exceptional } \\
\text { condition }\end{array}$ & $F_{z \lim }$ & 148860 & $F_{y \lim }$ & 49240 \\
\hline
\end{tabular}

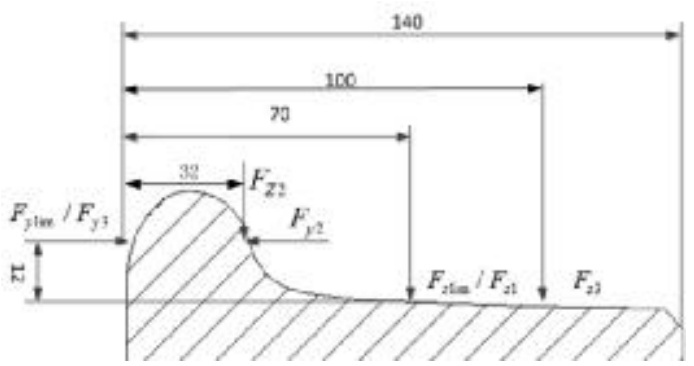

Fig. 3 The calculated load action position

\section{Calculation conditions and boundary conditions}

According to "UIC510-5 Technical approval of monolithic wheels (2003)" standard [9], strength calculation is divided into five calculation condition. Considering there is no relative movement between the wheel with the axle, so the fixed constraint is imposed on the surface of wheel hub hole. The calculate load action position as shown in figure 3.The load value as shown in table 2 .

\section{The results of calculation and analysis}

Using the finite element method analyze the stress distribution on the wheel under different working conditions. The wheel components under different conditions that stress distribution and maximum stress value as shown in table 3.

From table 3 shows, the maximum stress is $213.54 \mathrm{MPa}$ when wheel rim under the working condition of five kinds of computing, safety coefficient is 2.81 . The rubber body's maximum stress under the unexceptional condition is $1.65 \mathrm{MPa}$, safety coefficient is 2.12 , and in the exceptional condition, the rubber body's maximum stress within the scope of the allowable stress. Wheel center in the exceptional condition, the maximum stress is $90.28 \mathrm{MPa}$, the safety coefficient is 6.65 . Fixed ring in the exceptional condition that the maximum stress is $115.52 \mathrm{MPa}$, safety coefficient is 5.19. 
Figure 4 and figure 7 show the rubber body's stress distribution contour when elastic wheel under other conditions. By the figure shown, the maximum stress is $4.939 \mathrm{MPa}$ when rubber body under the exceptional condition. In normal driving conditions, the maximum stress is $2.673 \mathrm{MPa}$ while under turnout, safety factor of 1.31. Therefore, rubber body under various operating conditions, still has larger compression allowance, satisfies the requirement of strength of structure design.

Tab. 3 The results of stress contour of different conditions

\begin{tabular}{|c|c|c|c|c|}
\hline Component & $\begin{array}{l}\text { operating } \\
\text { conditions }\end{array}$ & $\begin{array}{l}\text { maximum } \\
\text { Von Mises } \\
\text { stress } \\
(\mathrm{MPa})\end{array}$ & $\begin{array}{l}\text { allowable } \\
\text { stress } \\
(M P a)\end{array}$ & maximum stress area \\
\hline \multirow{5}{*}{ wheel rim } & $\begin{array}{l}\text { assembly } \\
\text { condition }\end{array}$ & 0.79 & 400 & $\begin{array}{l}\text { On the interface between rim with the } \\
\text { rubber body }\end{array}$ \\
\hline & linear condition & 130 & 400 & Near the wheel/rail contact point \\
\hline & curve condition & 198.35 & 400 & Near the wheel/rail contact point \\
\hline & turnout & 130.94 & 400 & Near the wheel/rail contact point \\
\hline & $\begin{array}{l}\text { exceptional } \\
\text { condition }\end{array}$ & 213.54 & 600 & Near the wheel/rail contact point \\
\hline \multirow{5}{*}{ rubber body } & $\begin{array}{l}\text { assembly } \\
\text { condition }\end{array}$ & 0.31 & 3.5 & $\begin{array}{l}\text { interface between rubber body with } \\
\text { wheel rim }\end{array}$ \\
\hline & linear condition & 1.34 & 3.5 & $\begin{array}{l}\text { interface between rubber body with } \\
\text { wheel rim }\end{array}$ \\
\hline & curve condition & 1.65 & 3.5 & $\begin{array}{l}\text { interface between rubber body with } \\
\text { wheel rim }\end{array}$ \\
\hline & turnout & 1.34 & 3.5 & $\begin{array}{l}\text { interface between rubber body with } \\
\text { wheel rim }\end{array}$ \\
\hline & $\begin{array}{l}\text { exceptional } \\
\text { condition }\end{array}$ & 4.94 & 5 & $\begin{array}{l}\text { interface between rubber body with } \\
\text { wheel rim }\end{array}$ \\
\hline \multirow{5}{*}{ wheel center } & $\begin{array}{l}\text { assembly } \\
\text { condition }\end{array}$ & 0.51 & 400 & $\begin{array}{l}\text { interface between rubber body with } \\
\text { wheel center }\end{array}$ \\
\hline & linear condition & 6.87 & 400 & $\begin{array}{l}\text { interface between rubber body with } \\
\text { wheel center }\end{array}$ \\
\hline & curve condition & 17.91 & 400 & $\begin{array}{l}\text { interface between rubber body with } \\
\text { wheel center }\end{array}$ \\
\hline & turnout & 6.87 & 400 & $\begin{array}{l}\text { interface between rubber body with } \\
\text { wheel center }\end{array}$ \\
\hline & $\begin{array}{l}\text { exceptional } \\
\text { condition }\end{array}$ & 90.28 & 600 & $\begin{array}{l}\text { interface between rubber body with } \\
\text { wheel center }\end{array}$ \\
\hline \multirow{5}{*}{ fixed ring } & $\begin{array}{l}\text { assembly } \\
\text { condition }\end{array}$ & 0.52 & 400 & $\begin{array}{l}\text { interface between rubber body with } \\
\text { fixed ring }\end{array}$ \\
\hline & linear condition & 5.16 & 400 & $\begin{array}{l}\text { interface between rubber body with } \\
\text { fixed ring }\end{array}$ \\
\hline & curve condition & 4.36 & 400 & $\begin{array}{l}\text { interface between rubber body with } \\
\text { fixed ring }\end{array}$ \\
\hline & turnout & 5.16 & 400 & $\begin{array}{l}\text { interface between rubber body with } \\
\text { fixed ring }\end{array}$ \\
\hline & $\begin{array}{l}\text { exceptional } \\
\text { condition }\end{array}$ & 115.52 & 600 & $\begin{array}{l}\text { interface between rubber body with } \\
\text { fixed ring }\end{array}$ \\
\hline
\end{tabular}




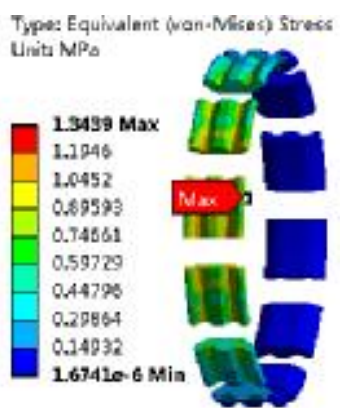

Fig. 4 Stress contour of rubber when wheel under linear condition

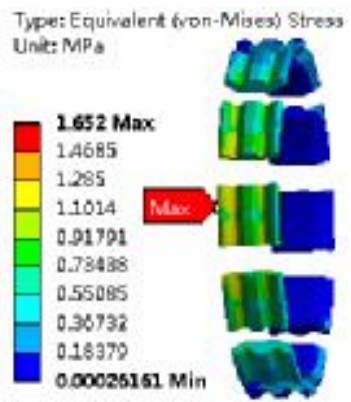

Fig. 5 Stress contour of rubber when wheel under curve condition

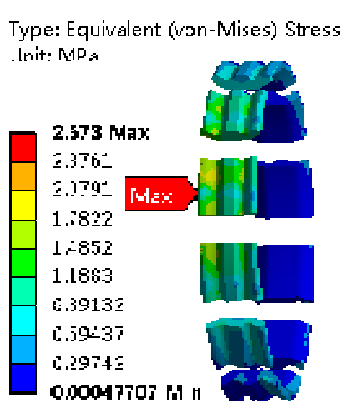

Fig. 6 Stress contour of rubber when wheel under turnout

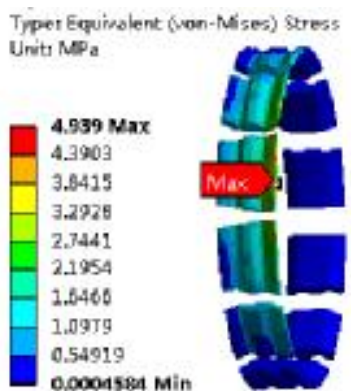

Fig. 7 Stress contour of rubber when wheel under exceptional condition

\section{Conclusion}

New W-shape elastic wheel is proposed, which has good application and reference value to the study of elastic wheel. Analysis shows that in the five different conditions, the wheel parts can satisfy the requirement of strength, and have bigger safety coefficient. Under the condition of assembly condition, the maximum stress area in the contact surface between the rubber body with other components, in other conditions, the maximum stress area near the scope of the loading point along the radial.

\section{Acknowledgements}

This work was financially supported by Natural Science Foundation project of China (11302159).

\section{References}

[1] WANG Bin, LIU De gang. The application solutions explore of new subway vehicle noise daming wheel[J]. Rolling Stock 2014, 52(4):7-11.

[2] FANG Jianying, XIAO Xinbiao, JIN Xuesong, LI Yinghui. Effect of Train Speed on Acoustic Radiation Characteristics of High-speed Train Wheel Vibration[J]. Journal of Mechanical Engineering. 2010, 46(22):96-104.

[3] CU Yongping, TANG Yongming, ZHOU Jinsong. The subway wheel noise reduction research [J]. China Railway Science,2012,33(1):98-103.

[4] HEMSWORTH B. Recent Developments in Wheel/Rail Noise Research[J]. Journal of Sound and Vibration, 1979,66(3):297-31.

[5] WEN Juan, LI Fu, YANG Yang, DING Jun-jun. Parameters Optimization and Track Adaptation Research of Urban Vehicle Resilient Wheels[J]. Electric Drive For Locomotives,2015(3) :74-77. 